\title{
Observation ICSR Terminology
}

National Cancer Institute

\section{Source}

National Cancer Institute. Observation ICSR Terminology. NCI Thesaurus. Code C88088.

Terminology used in Individual Case Safety Reports for observations related to reporting adverse events. 